\title{
Including students with disabilities in Learning Communities
}

\author{
Silvia Molina* and Oriol Ríos \\ Universitat Rovira i Virgili \\ (Received November 25, 2009; Accepted February 18, 2010)
}

\begin{abstract}
Learning Communities is a project for school transformation the objective of which is to achieve high quality education for all students, avoiding all type of segregation due to students' level of attainment or other characteristics, and any type of differentiation or acritical adaptation of the curriculum, which may lead to unequal learning results. Students with disabilities have traditionally been subject to these types of practices which, nevertheless, have dubious results as far as the learning and social integration of these students is concerned. It is necessary to identify educational strategies which respond to the specific needs of these students within the framework of the same educational environment and the same learning objectives, as is being claimed from the inclusive education perspective. Starting from these premises, in this article we review the Learning Communities model as a school model which contributes to the inclusion of students with disabilities. Firstly, we will define the term "disability" and its educational implications as compared to other concepts which have also been used in this field. Secondly, we describe some of the characteristics of the learning communities in relation to inclusive education and we focus particularly on the way in which the learning communities approach responds to the specific educational needs of students with disabilities. Finally, we will focus on a specific classroom practice, the interactive groups, and its contributions to the inclusion of students with disabilities.
\end{abstract}

Keywords: learning communities, students with disabilities, inclusion.

La inclusión de alumnado con discapacidad en las Comunidades de Aprendizaje RESUMEN: Las Comunidades de Aprendizaje son un proyecto de transformación de los centros educativos cuyo objetivo es conseguir una educación de calidad para todo su alumnado, evitando todo tipo de segregación en función del nivel de aprendizaje o de otras características, y cualquier tipo de diferenciación o adaptación acrítica del currículum que pueda llevar a resultados educativos desiguales. El alumnado con discapacidad es un colectivo que tradicionalmente ha sido objeto de este tipo de prácticas, que sin embargo aportan resultados dudosos tanto en cuanto a su aprendizaje como a su integración social. Es necesario identificar estrategias educativas que den respuesta a las necesidades específicas de este alumnado en el marco de un mismo entorno y unos mismos objetivos de aprendizaje, tal como se viene defendiendo desde la educación inclusiva. Partiendo de estas premisas, en este artículo revisamos el modelo de las Comunidades de Aprendizaje como modelo de escuela que contribuye a la inclusión del alumnado con discapacidad. En primer lugar, situamos conceptualmente el término "discapacidad" y sus implicaciones educativas frente a otros conceptos que 
también se han venido utilizando en este ámbito. En segundo lugar, describimos algunas de las características de las comunidades de aprendizaje en relación a la educación inclusiva, y nos centramos especialmente en cómo el planteamiento de las comunidades de aprendizaje responde a las necesidades educativas específicas del alumnado con discapacidad. Por último, nos centramos en una práctica de aula concreta, los grupos interactivos, y sus contribuciones a la inclusión del alumnado con discapacidad.

Palabras clave: comunidades de aprendizaje, alumnado con discapacidad, inclusión.

\section{INTRODUCTION}

In the current society, educational systems and strategies should be designed in order to respond to all students' needs, and trying to not forget those who have the highest risk of social exclusion. As the European Union highlighted in 2000, the access to knowledge and ICT will be the tools that will better respond to this challenge. The Lisbon Strategy takes the relevance of education in the knowledge society into account, as well as the need to fight against any kind of discrimination:

In defining and implementing its policies and activities, the Union shall aim to combat discrimination based on sex, racial or ethnic origin, religion or belief, disability, age or sexual orientation (European Council, 2000, p. 49)

In this context, the aim of inclusive education is to promote high expectations and the best learning conditions for all students, especially focusing on the most vulnerable groups of students, such as the children with some kind of disability. These students can find more difficulties to progress within the educational system due to practices of segregation or curriculum adaption which sum with their individual difficulties and have exclusionary consequences which limit their learning possibilities and further social inclusion (Ainscow, 1994; 2003; Ainscow, Booth \& Dyson, 2004; Puigdellívol, 2005; Elboj, Puigdellívol, Soler \& Valls, 2002). In this article we start from Ainscow's $(1994,2003)$ conceptualization of inclusion in education, which involves attendance, participation and academic performance of all students (2003, p. 13). We will present evidence of the way in which the approach of the Learning Communities and the practices included in them demonstrate to contribute to the educational inclusion of students with disabilities.

\section{DEFINING “DISABILITY” AND ITS EDUCATIONAL IMPLICATIONS}

After approaching the concept of inclusive education in the previous section, in this section we will focus on other relevant concepts commonly used when analysing the situation of students with disabilities. 
Special educational needs is a frequently used concept. It was adopted for the first time in Warnock Report published in the United Kingdom in 1978 by the "Committee of Enquiry into the education of handicapped children and young people". The Report reflects the need to redefine the categorization of students with disabilities because the terms used before were highly pejorative. The concept "educational need" was introduced to refer to the distance which exists between people's capacities and social demands; in relation to this, the educational system performs the function of responding to people's educational needs so that they can be included in society. This new concept replaced that of "special education" and the subsequent implications of educating students with disabilities in special schools separated from the mainstream ones (UNESCO, 1997), and thus involved transformations as regards the educational approach aimed at these students. However this new concept, which was less focused on the students' particular difficulties but on the educational provision, soon started to be used more individually and to include children with learning difficulties due to very diverse reasons.

The idea of impairment refers to those limitations which are due to physical, sensorial, motor or psychic causes. These problems affect the normal development of children as well as their learning process. The idea of disability refers to the consequence of the impairment in relation to people's adaptation to the context. The traditional conceptualization based on the impairment was frequently used from the perspective of special education, which focused on children's limitations and subsequent classifications, and lead to low expectations of students' academic performance (Puigdellívol, 1995). On the contrary, the idea of 'disability' gives education the possibility to intervene; social interactions and other elements of the context can contribute to reduce the disability, and therefore the educational practices play a leading role in this reduction process because these can promote the strengthening of children's capabilities in spite of their impairment. It is the school's responsibility to ensure that students with disabilities know their capacities and that they learn to use them (Puigdellívol, 2003).

\section{LEARNING COMMUNITIES AS INCLUSIVE SCHOOLS AND THE EDUCATION OF STUDENTS WITH DISABILITIES}

In this section we will focus on some of the characteristics of the Learning Communities which help responding to the specific educational needs of students with disabilities from an inclusive perspective.

Learning Communities has been defined as a project of social and cultural transformation of an educational centre and its environment to achieve an Information Society for all, based on the Dialogic Learning and through the participation of the community in all spaces included the classroom (Elboj et al., 2002). The main objective of the learning communities is to achieve a better learning and coexistence among all their members, regardless of their particular characteristics. Students with disabilities have more difficulties than the other students to 
both achieve good learning results and have normalized and satisfactory relationships with their peers. For this reason, this project is an educational environment which facilitates the inclusion of these students in both senses.

The dialogic learning (Flecha, 2000; Aubert, Flecha, García, Flecha \& Racionero, 2008) that the learning communities are based on, has the premise that learning is constructed through egalitarian dialogue and interactions between people. These interactions include those which take place in the regular classrooms, between teachers and students, but also take into account the fact that learning also occurs out of the classroom and the school, in the interaction with other educational agents, that is, other members of the community.

Different characteristics of the learning communities contribute to the inclusion of students with disabilities. First of all, the learning communities are a response to diversity in schools. The objective of the learning communities is that all their students can achieve educational success to be fully included in society. This is an objective of equality, but this equality takes also into account the differences between students -in terms of culture, ethnicity, gender, ability or others- from the principle of the equality of differences (Flecha, 2000), that is, all the different identities are respected and valued and at the same time all the students are offered the means to achieve educational success.

This goes along with the fact that, in the learning communities, promoting the inclusion of students with disabilities is part of the global approach of the project. As it is defended from the inclusive perspective (Ainscow, 1994), creating schools which promote the learning of all their students, whatever their characteristics are, also constitute a good framework to promote the learning of students who have more difficulties and those with disabilities. Therefore, students with disabilities can be included in these schools as a part of their global objective of providing the best learning context for all students.

One particular characteristic of the learning communities which contributes to responding the different students' needs and also those of students with disabilities is the inclusion of the additional resources in the classroom. While traditionally students with disabilities have been educated separately, either in separated schools or in separated classrooms within mainstream schools, sufficient research has shown that the education of students with disabilities in segregated placements does not contribute to better results. Research carried out by Dunn (1968), Fitch (2003) and Fisher, Roach and Frey (2002) demonstrated that segregated groupings for students with disabilities are associated with a lower feeling of capacity, lower self-confidence on their competence and academic performance, lower self-esteem and expectations, and lower performance. The PISA (Programme for International Student Assessment) reports of 2003 and 2006 also provided data on the fact that most integrative educational systems, based on heterogeneity, are obtaining best results in instrumental skills, like maths or reading (OECD, 2005, 2007), while schools that divided students by ability for all subjects tended to have lower student performance (OECD, 2007, p. 37), therefore these systems are more closer to equality than those which are favouring 
homogeneous classrooms.

Furthermore, the scientific literature shows that there is a difference not only between segregated and non-segregated settings, but specifically between inclusive and non-inclusive placements. This is because inclusion means not only schooling in a non-segregated setting, but means also a redefinition of schooling. One characteristic of this redefinition is including supports and services of special education and others in the ordinary classroom. Instead of addressing the support to particular students, it can be also addressed to the school staff, the class teacher, the pedagogic assessment teams, the families and the communities, in order to make possible that students with disabilities can attend the regular classroom and receive there the necessary support (Meijer, Soriano \& Watkins, 2003; Porter, 1997, 2003; Puigdellívol, 2005).

In the learning communities any type of separation of students according to their level of attainment or ability is avoided, and practices which promote the access to the necessary support within a shared learning environment are developed. The interactive groups, which are described in the next section, are an example of inclusive practices which are put into practice in the learning communities.

Another characteristic which contributes to the educational inclusion of students with disabilities is related to the social model of disability which some authors have associated to inclusion (Chenoweth \& Stehlik, 2004; Nind \& Cochrane, 2002). Other authors have emphasised the fact that the abilities and disabilities are not individual characteristics but collective characteristics. Del Río (1998) quotes Vygotsky's (1989) statement that, in its origin, all the functions are distributed amongst different persons, and describes the formula of the interdependence and of the shared and incomplete abilities which, according to the author, made possible the development of the specie (phylogeny) and every day makes possible the development of each human being (ontogeny) (Del Río, 1998, p. 37). When schools are based on an interactive approach, as occurs in the learning communities, students' difficulties are considered in relation with the school practices. As a consequence, disabilities are not considered only individual characteristics, but something which also depends on the learning context, school practices, and teachers' attitudes.

Finally, in the learning communities, the access to common learning contents and high expectations for all their students are promoted. Educational inclusion emphasises that the general curriculum can be available to all the students, also for those with disabilities. Starting from the general curriculum, some specific adaptations may be necessary, however, any adaptation should be carried out keeping in mind that the learning contents that any student learn has to be aimed at preparing them to be competent members of society. According to this, the access to the same learning contents for all students is promoted in the learning communities. On the one hand, high expectations are posed towards the learning possibilities of all the students, also for students with learning difficulties or disabilities; on the other hand, these schools are based on the belief that every person, regardless their educational background or social position, has capacities and 
these can contribute to the students' learning (Duque \& Garcia, 2003; Puigdellívol, 2003). Therefore, instead of lowering down the learning objectives in order to adapt to the particular level of achievement of a student or a group of students, all the resources and supports which are considered necessary are introduced in the school and in the classroom, and the learning context is transformed so that all the students have the possibility to achieve the best results. As a consequence, even students with disabilities can work the same contents and the same activities than their peers with the necessary support. In the learning communities the aim of all the community, including families, volunteers, teachers and the neighbourhood, is to accelerate the learning of all the students, and that everybody can achieve the same results. In these schools a community agreement exists about the learning of each student: each student is important and every person involved in the school is responsible to ensure that nobody is left behind. In this sense, students with learning difficulties and with disabilities are not excluded but they receive the necessary attention from the school with the objective to ensure their inclusion in the classroom and the improvement of their academic performance (Ortega \& Puigdellívol, 2004).

\section{INTERACTIVE GROUPS AS AN INCLUSIVE PRACTICE FOR STUDENTS WITH DISABILITIES}

Within the framework of the learning communities, there is a specific classroom practice which has been proved to contribute to improving students' learning and good coexistence among them. The interactive groups consist of dividing the classroom in a number of heterogeneous groups of students, usually to work in instrumental subjects, with the help of volunteer adults from the community. Specifically, the interactive groups have demonstrated to facilitate the inclusion of students with disabilities who, through this practice, can participate more easily in the regular learning activities of the ordinary classroom. Interactive groups is a practice which is opposite to the practices of ability grouping, which segregate students according to their ability, and also to remedial classes and the provision of support segregated from the regular classroom, which are practices often aimed at students with disabilities. The inclusion of students with disabilities is facilitated in the interactive groups due to the fact that these groups involve a transformation of the learning environment, and this is mainly achieved through the increased possibilities of interaction which exist in these groups.

On the one hand, in the interactive groups learning interactions occur between students. Children are encouraged to help each other, as promoted by the principle of solidarity (Flecha, 2000), and therefore the existing diversity among students becomes a positive resource for learning, as students can find the help they need to do the activity in other students who have different abilities or who are more proficient in that subject. On the other hand, learning is promoted through the interaction with other members of the community. In each interactive group there is a family member or another adult from the community who 
volunteer to help students with the classroom activity. In these groups, volunteers help by giving support directly to any student who needs it and by encouraging interaction and mutual support between students. When students with disabilities participate in the interactive groups, they find the opportunity to receive the support they need from their peers or from the adults, and this occurs as a part of the regular development of the activity. Besides, if necessary, other supports can be included; for instance, the special education teacher has participated in some cases in the interactive group where the student with disability is, in order to help them (Molina, 2007).

The contributions of relevant authors in the fields of education, psychology and sociology are in the essence of the learning communities, and also in the fundamentals of the interactive groups. These contributions also allow explaining the increased learning possibilities of students with disabilities within the interactive groups. Vygotsky (1979) highlighted the relevance of the sociocultural context for the development of the linguistic and intellectual abilities. Social interaction in the learning processes makes a difference between the development of the elemental (biological) processes and the higher psychological processes. Besides, Freire (1997) defended the possibility to transform the context, which is a result of the human action, as well as the transformative power that education has to overcome inequalities between people. Along these lines, the interactive groups are based on the fact that the context has a very important role in the learning processes and that it is necessary to transform it to improve the learning conditions.

An element which is associated to the transformation of the learning context is the interactions with other people, which have a central role in the development of the intellectual capabilities and the academic performance. Bruner (1997) referred to the possibility of learning which appears when students interact among them, some times teaching to others and other times learning from them, in a bidirectional learning relationship. Vygotsky's Zone of Proximal Development (1979) explains that children can learn from interactions much more than by themselves. These interactions work in the zone between the actual developmental level and the potential developmental level, and include interactions both with adults and with other children. Mead (1973) distinguished between the "self", "me" and "I". The "self" is socially constructed based on the experiences with the others, which are incorporated. As the interactions are at the centre of the creation of meanings and of the learning processes, when the number and the diversity of interactions increase the learning achievement is promoted.

Along with the influence that context has on learning and the relevance of learning interactions, some authors highlight the universal ability of language and its role for learning. According to Chomsky $(1968,2000)$ the universal faculty of language makes possible the existence of dialogue and communication between people as something which is also universal. According to Vygotsky, language and action are part of the same complex psychological function; there is a dynamic relationship between both of them, and as consequence the more 
difficult the task, the more children need to talk. Wells (2001) also argued that the interactions through dialogue are very important in the creation of knowledge and learning; within a group, knowledge is created through the collaborative contributions of each of its members about their comprehension of the problem, and at the same time the different members increase their learning through their participation in this group.

Finally, the interactions through language that lead to a context transformation which reinforces learning and contribute to achieving democratic educational practices are those interactions based on egalitarian dialogue. Habermas (1987) in the Theory of Communicative Action conceptualises the communicative rationality as the rationality which uses the knowledge to get an agreement to do something, and the communicative action as the action that takes place when the actors want to get an agreement about a situation or about the action plan to achieve an objective. According to Habermas, all persons have the ability of language and action, and therefore all persons can participate in communicative actions. In a similar way, Freire (1980) in his Theory of Dialogical Action explains the dialogical actions as those oriented to understanding, transformation and liberation, in front of those which favour the reproduction of power.

As a result of the transformation of the learning environment which occurs with the interactive groups, through the learning interactions based on an egalitarian dialogue, and the inclusion of additional resources, this practice contributes both to better learning conditions for students with disabilities and to better conditions for an increased participation and social integration of these students (Molina, 2007).

As regards the contributions to the learning possibilities, first of all, working in interactive groups facilitates that students with disabilities spend a high proportion of the class time involved in the learning activity. Five observations which were carried out in classrooms where students were working in interactive groups made it possible to observe that students with disabilities spent between the $79 \%$ and the $100 \%$ of the class time either working in the activity or paying attention to the learning interactions which occurred in the group. Secondly, a high level of motivation is perceived among these students when they work in interactive groups, as compared to working separately with the special education teacher; the possibility of working together with other classmates, in the same activities that they do, and the presence of family and community members different to the teachers contribute to this increased motivation. Thirdly, the possibility of working together with the other peers and in the same activities as them contributes to creating less differences between these students and the others, and therefore to higher expectations towards them.

Fourthly, the group members and the adult volunteers are a source of help for all the children, and when there are students with disabilities in these groups they can take advantage of this help which is available for all the group. Students with disabilities can also learn from their peers and from the volunteers just by paying attention to the learning interactions which occur in the group (although 
these may not be aimed at them). Furthermore, not only students with disabilities benefit from participating in the interactive groups, but the other students can also benefit from the presence of a student with a disability in the group; sometimes the child with a disability is the one who offers his or her help to another child in those learning contents in which he or she is proficient, other times the explanations and learning interactions which occur in the group in order to help the student with a disability can also benefit the other students. Finally, it is worth highlighting the role of the volunteer in the group, who promotes these learning interactions within the group in the case that these do not occur spontaneously.

With regards to the contributions of interactive groups to the participation and social integration of students with disabilities, the helpful interactions which occur in these groups are one way to promote the participation of students with disabilities within the group. At the same time, the acceptation and social integration of these students in the group is also promoted through these helpful interactions, as they contribute to make that the other children know better the students with disabilities, their difficulties but also their abilities, and therefore allow transforming stereotypes and prejudices about them. The volunteers from the community have also a relevant role in promoting the participation of everyone within the group and emphasising those contents in which the students with disabilities succeed and can contribute to the group, thus promoting a positive image of them.

\section{CONCLUSION}

In this article we have described the learning communities as an educational approach that contributes to the inclusion of students with disabilities. We have reviewed some of the main characteristics of the learning communities which respond to the inclusive approach. These characteristics demonstrate the capacity of this project to include very diverse students, also those with disabilities, into the way in which they function, and fight against the educational segregation which leads to unequal achievement.

These characteristics include the global objective of providing high quality education and achieving good coexistence for all their diverse children, the implementation of practices which do not separate students according to their level of attainment but which include in the classroom all the necessary resources, the importance given to the interactions in the learning context which is related to a social model of disability, the promotion of high expectations and the access to the common learning contents for all the students.

Finally, we have described a particular classroom practice, the interactive groups, and their theoretical basis. We have also described the way in which their two main elements - the interaction among students and the participation of the community-contribute to the learning achievement, participation and social integration of students with disabilities.

The analysis that we have made allow concluding not only that the learning 
communities contribute to the educational inclusion of students with disabilities, but also the fact that this inclusive approach benefits the rest of students and the community as a whole.

\section{REFERENCES}

Ainscow, M. (1994). Special Needs In The Classroom: A Teacher Education Guide. Paris: UNESCO.

Ainscow, M. (2003). Desarrollo de Sistemas Educativos Inclusivos, La respuesta a las necesidades educativas especiales en una escuela vasca inclusiva. Organises: Gobierno Vasco: San Sebastián.

Ainscow, M., Booth, T., \& Dyson, A. (2004). Understanding and developing inclusive practices in schools: a collaborative action research network. International Journal of Inclusive Education, 8(2), 125-139.

Aubert, A., Flecha, A., García, C., Flecha, R. \& Racionero, S. (2008). Aprendizaje dialógico en la Sociedad de la Información. Barcelona: Hipatia.

Bruner, J. (1997). La educación, puerta de la cultura. Madrid: Visor.

Chenoweth, L., \& Stehlik, D. (2004). Implications of social capital for the inclusion of people with disabilities and families in community life. International Journal of Inclusive Education, 8(1), 59-72.

Chomsky, N. (1968). Language and mind. Enlarged edition. New York: Harcourt Brace Jovanovich, Inc.

Chomsky, N. (2000). New Horizons in the Study of Language and Mind. Cambridge: Cambridge University Press.

Del Río, P. (1998). De la discapacidad como problema a la discapacidad como solución: el largo camino recorrido por el pensamiento defectológico desde L. S. Vygotski. Cultura y Educación, 11/12, 35-57.

Dunn, L. M. (1968). Special Education for the Mildly Retarded. Is much of it justifiable? Exceptional Children, 35, 5-22.

Duque, E., \& García Yeste, C. (2003). Comunidades de aprendizaje: la inclusión de todos los niños y niñas. Aula de Innovación Educativa, 121, 53-55.

Elboj, C., Puigdellívol, I., Soler, M., \& Valls, R. (2002). Comunidades de aprendizaje. Transformar la educación. Barcelona: Graó.

European Council. (2000). Presidency Conclusions. Lisbon European Council. Lisbon: EC.

Fisher, D., Roach, V., \& Frey, N. (2002). Examining the general programmatic benefits of inclusive schools. International Journal of Inclusive Education, 6(1), 63-78.

Fitch, F. (2003). Inclusion, Exclusion, and Ideology: Special Education Students' Changing Sense of Self. Urban Review 35(3), 233-252.

Flecha, R. (2000). Sharing Words. Lanham, M.D: Rowman \& Littlefield Freire, P. (1980). Pedagogía del oprimido. Madrid: Siglo XXI.

Freire, P. (1997). A la sombra de este árbol. Barcelona: El Roure.

Habermas, J. (1987). Teoría de la acción comunicativa. Madrid: Taurus 
Mead, G. H. (1973). Espíritu, persona y sociedad. Desde el punto de vista del conductismo social. Barcelona: Paidós.

Meijer, C., Soriano, V., \& Watkins, W. (2003). Special Needs Education in Europe, Thematic publication of the European Agency for Development in Special Needs Education.

Molina, S. (2007). Los grupos interactivos: una práctica de las comunidades de aprendizaje para la inclusión del alumnado con discapacidad. (Non published doctoral theses). Barcelona: Universitat de Barcelona.

Nind, M., \& Cochrane, S. (2002). Inclusive curricula? Pupils on the margins of special schools. International Journal of Inclusive Education, 6(2), 185-198.

OECD. (2005). School Factors Related to Quality and Equity. Results From PISA 2000. París: OECD.

OECD. (2007). PISA 2006 Science Competencies for Tomorrow's World. Results form PISA 2006. París: OECD.

Ortega, S., \& Puigdellívol, I. (2004). Incluir es sumar. Comunidades de aprendizaje como modelo de escuela inclusiva. Aula de Innovación Educativa, 131, 47-50.

Porter, G. L. (1997). Critical elements for Inclusive Schools. In S.J. Pijl, C.J.W. Meijer \& S. Hegerty (Eds.), Inclusive Education, a Global Agenda. Londres: Routledge Publishing.

Porter, G. L. (2003): El reto de la diversidad y la integración en las escuelas. Aula de Innovación Educativa, 121, 37-42.

Puigdellívol, I. (2003). Integración educativa: un cambio en la concepción de la discapacidad y de la escuela. Cero en conducta, 50, 5-29.

Puigdellívol, I. (2005). La educación especial en la escuela integrada: una perspectiva desde la diversidad. Barcelona: Graó.

UNESCO. (1997). International Standard Classification of Education ISCED 1997.

Vygotsky, L. S. (1979). El desarrollo de los procesos psicológicos superiores. Barcelona: Crítica.

Vygotsky, L. S. (1989). Concrete Human Psychology. Soviet Psychology, 27 (2), 53-77.

Wells, G. (2001). Indagación dialógica. Hacia una teoría y una práctica socioculturales de la educación. Barcelona: Paidós. 